\title{
INNOVATIONS OF TEACHER TRAINEES PREGRADUAL TRAINING AIMED AT FORMING THEIR DIGITAL COMPETENCES
}

Ján ZAHOREC*, Univerzita Komenského v Bratislave, Slovenská republika Alena HAŠKOVÁ, Univerzita Konštantína Filozofa v Nitre, Slovenská republika

Adriana NAGYOVÁ, Univerzita Komenského v Bratislave, Slovenská republika

Přijato: 9. 6. 2020 / Akceptováno: 16. 7. 2020

Typ článku: Teoretická studie

DOI: $10.5507 /$ jtie.2020.013

Abstract: In the paper there are presented some results of research survey of current state and needs to innovate teacher trainees pregradual training in the field of development their didactic-technological competences. Within the research survey, from the point of view of a research sample of 280 teacher trainees, measure of significance of selected software applications in relation to the development of professional digital literacy of teachers was assessed. Results of statistical analysis of the collected data pointed out some important facts that should be reflected in innovations of the relevant area of curricula of teacher study programs at universities, or also in programs of further education of inservice teachers. As follows from the presented results, into the teacher training study programs, in addition to the traditionally taught use of software applications Microsoft Word, Microsoft Excel and Microsoft PowerPoint, there should be included, or strengthened, also teaching of such software applications as ActivInspire, FreeMind, Flow! Works, Google Docs and, if possible, FreeMind, Mindomo, XMind and Prezi.

Key words: teacher training, curricula design, didactic-technological competences, software applications. 


\section{INOVÁCIE PREGRADUÁLNEJ PRÍPRAVY UČITELOV V ZAMERANÍ NA FORMOVANIE ICH DIGITÁLNYCH KOMPETENCIÍ}

Abstrakt: V príspevku sú prezentované niektoré výsledky výskumného šetrenia súčasného stavu a potrieb inovácii pregraduálnej prípravy učitel'ov v oblasti rozvíjania ich didakticko-technologických kompetencií. V rámci výskumného šetrenia bola z pohl'adu výskumnej vzorky 280 študentov učitel'stva posudzovaná miera významnosti vybraných softvérových aplikácil vo vztahu $k$ rozvíjaniu profesijnej digitálnej gramotnosti učitelov. Výsledky štatistickej analýzy výskumných dát preukázali určité významné skutočnosti, ktoré by mali byt' premietnuté do inovácii prislušnej oblasti kurikúl študijných programov učitel'stva na vysokých školách, resp. aj do programov d'alšieho vzdelávania učitel'ov. Ako vyplýva z prezentovaných výsledkov, okrem tradične vyučovaného použivania softvérových aplikácií Microsoft Word, Microsoft Excel a Microsoft PowerPoint $v$ študijných programoch by mala byt' zaradená, resp. posilnená aj výučba didaktických softvérových aplikácií ako sú ActivInspire, FreeMind, Flow!Works, Google Dokumenty a podl'a možností aj FreeMind, Mindomo, XMind a Prezi.

Klúčové slová: pregraduálna príprava učitel'ov, návrh učebných osnov, didakticko-technologické kompetencie, softvérové aplikácie.

*Autor pro korespondenci: zahorec@fedu.uniba.sk 


\section{1 Úvod}

Pregraduálna profesijná príprava budúcich učitel'ov pozostáva z dvoch častí. Jednou je teoretická príprava v oblasti pedagogiky, psychológie a vedných odborov vyučovacích predmetov (akademických, profesijných, umelecko-výchovných a výchovných predmetov) zameraná na osvojenie si náležitých vedomostí a druhou je praktická príprava zameraná na rozvíjanie schopnosti učitel'ov uplatňovat' nadobudnuté vedomosti v praktickej rovine výkonu učitel'ského povolania. Ako upozorňujú významné osobnosti zaoberajúce sa problematikou prípravy učitel'ov, kým teoretická príprava postupne po roku 1989 dosahuje univerzitnú úroveň porovnatel'nú so zahraničím, didaktická a praktická príprava v globálnom hodnotení pedagogických fakúlt nedosahuje univerzitný charakter a ostáva na úrovni realizácie praxe porovnatel’nej so strednými pedagogickými školami (Kosová, Tomengová a kol., 2015).

S problematikou kompetenčného profilu učitel'ov, ich schopnosti uplatňovat' profesijné kompetencie pri výkone svojej pedagogickej činnosti, súvisia dva v minulom roku ukončované projekty, z ktorých jeden sa riešil na Univerzite Komenského v Bratislave a druhý na Univerzite Konštantína Filozofa v Nitre. Projekt riešený na UKF v Nitre bol zameraný podstatne širšie (projekt APVV-14-0446 Hodnotenie kompetencii učitel'a, 2016 - 2019), s hlavným zameraním na vývoj nástrojov hodnotenia jednotlivých kompetencií učitel'a, t. j. aj kompetencie digitálnej gramotnosti. Projekt riešený na UK v Bratislave (projekt KEGA 041UK-4/2017 Inovácia pregraduálnej prípravy učitelov v oblasti didakticko-technologických kompetencií, 2017 - 2019) bol špecifikovaný užšie, s hlavným zameraním na analýzu začleňovania predmetov zameraných na uplatňovanie moderných digitálnych technológií vo vyučovaní predmetov na základných a stredných školách do študijných programov odbornej prípravy učitel'ov. Medzi hlavné výstupy prvého z uvedených projektov možno zaradit' publikácie Magová a kol. (2016), Lomnický a kol. (2017), Boboňová a kol. (2017), Sandanusová a kol. (2018), Stranovská a kol. (2018), Szíjjártóová a kol. (2019), Čeretková a kol. (2019), Gadušová a kol. (2019). Druhý $\mathrm{z}$ uvedených projektov bol ukončený v decembri minulého roku (2019). Priebežné výsledky boli prezentované na rôznych medzinárodných fórach doma i v zahraničí (Záhorec, Hašková, Munk, 2018; 2019; Záhorec, Nagyová, Hašková, 2019) a začiatkom roku 2020 vyšla výstupná monografia autorského kolektívu Záhorec, Hašková a Munk (2020).

Nakol'ko obidva projekty majú určité styčné body, počas ich riešenia dochádzalo k neformálnej vzájomnej spolupráci niektorých členov príslušných riešitel'ských kolektívov. Uvedené sa týka aj v d’alšom prezentovaných výsledkov.

\section{Metodika výskumného šetrenia}

Ako je uvedené už v úvode, zámerom projektu Inovácia pregraduálnej prípravy učitel'ov v oblasti didakticko-technologických kompetencií bolo vytvorenie platformy pre návrh optimálneho modelu pregraduálnej prípravy učitel'ov v oblasti didaktickotechnologických kompetencií, s akcentom na formovanie ich profesijnej digitálnej gramotnosti. Súčast'ou rozsiahleho výskumu, realizovaného v rámci predmetného projektu, bolo posúdenie miery dôležitosti začlenenia rôznych druhov digitálnych didaktických prostriedkov do kurikúl pregraduálnej prípravy učitel’ov vzhl'adom na úspešnost' výkonu učitel'skej profesie. 
Respondentmi výskumného šetrenia bolo 280 študentov učitel'stva (205 na Slovensku, 75 v Čechách; 49 mužov, 231 žien), ktorí vyjadrovali svoje názory, respektíve posudzovali mieru dôležitosti začlenenia deviatich tematických okruhov, učebných tém zameraných na prácu s vybranými druhmi digitálnych didaktických produktov, do kurikúl ich pregraduálnej prípravy vo vzt’ahu $\mathrm{k}$ úspešnosti výkonu ich budúcej profesie, t. j. vo vzt’ahu k potrebám a požiadavkám učitel’ov vzhl'adom na úspešný profesionálny výkon ich pedagogickej činnosti.

Na skríning názorov výskumnej vzorky študentov smerom k uvedenému výskumnému zámeru bol použitý nami vytvorený dotazník obsahujúci položky faktografického charakteru (oblast' A) a devät' tematických oblastí (rôznych druhov softvérových produktov), ku ktorým sa mali respondenti v rámci dotazníkového dopytovania vyjadrovat' (vid' položky B1 - B9 prezentované v Tab. č. 1). Výber uvedených tematických oblastí (jednotlivých druhov softvérových produktov) v podstate reflektuje vývojové tendencie a situáciu na základných a stredných školách na Slovensku, čo sa týka ich materiálnotechnickej vybavenosti.

Respondenti - študenti učitel'stva každú z uvedených tematických oblastí B1 - B9 (t. j. problematiku ovládania práce $\mathrm{s}$ daným softvérovým produktom a možnosti jeho využívania $\mathrm{v}$ rámci vyučovania jednak vo všeobecnosti a jednak v zameraní na výučbu konkrétnych predmetov) posudzovali $\mathrm{z}$ viacerých hladísk. Z dôvodu obmedzeného priestoru prezentujeme len výsledky dopytovania zameraného na posudzovanie tematických oblastí B1 - B9 z nasledujúcich dvoch hladísk:

a) z hladiska významnosti/dôležitosti zaradenia príslušnej problematiky ako učebnej témy do študijných programov pregraduálnej prípravy učitel'ov (Tab. č. 2, odpovede B1.1 - B9.1),

b) z hladiska optimálnej časovej dotácie predmetu, $\mathrm{v}$ rámci ktorého by sa príslušná učebná téma vyučovala (Tab. č. 3, odpovede B1.2 - B9.2).

$\mathrm{V}$ prípade prvého hladiska vyjadrovali respondenti svoje názory prostredníctvom 6bodovej škály s hodnotami 6 - rozhodne zaradit'; 5 -zaradit; 4 -asi je potrebné zaradit'; 3 - asi nie je potrebné zaradit'; 2 - nezaradit'; 1 - rozhodne nezaradit'. Vol'bu neutrálneho, emočne indiferentného hodnotiaceho postoja sme zámerne nezaradili, nakol'ko sme chceli od respondentov získat' vyhranené názory na posudzovanú problematiku.

\begin{tabular}{cl}
\hline $\begin{array}{l}\text { Označenie } \\
\text { uč. témy }\end{array}$ & Obsahové zameranie posudzovanej učebnej témy \\
\hline B1 & $\begin{array}{l}\text { počítačové aplikácie akými sú napríklad ActivInspire, SMART } \\
\text { Notebook alebo Flow!Works, určené na tvorbu elektronických } \\
\text { vzdelávacích aktivít, interaktívnych úloh a vedomostných hier pre } \\
\text { oblast' regionálneho školstva } \\
\text { internetová (online) aplikácia Prezi určená na vytváranie nelineárnych } \\
\text { dynamických prezentácií (nie len) edukačného obsahu využitel'ných vo } \\
\text { výchovno-vzdelávacích aktivitách } \\
\text { počítačové / tabletové aplikácie akými sú napríklad FreeMind, } \\
\text { Bindomo, XMind určené pre vytváranie myšlienkových máp }\end{array}$ \\
B3 &
\end{tabular}


využitel’ných vo výchovno-vzdelávacích aktivitách so žiakmi, vrátane žiakov so špeciálnymi výchovno-vzdelávacími potrebami

B4 moderné interaktívne hlasovacie systémy, akými sú napríklad ActivExpression2, ActiVote, QRF700/900, TurningPoint, prostredníctvom ktorých je možné klást' otázky s ciel'om overovania, testovania a hodnotenia vedomostí žiakov vo vyučovaní

B5 internetová aplikácia Socrative 2.0 učená na online overovanie, testovanie a hodnotenie vedomostí žiakov vo vyučovaní, ale aj mimo neho

B6 moderné nástroje kolaboratívnej tvorby a správy elektronických online dokumentov, akými sú napríklad Dokumenty Google, cestou využívania aktuálnych možností internetu kategórie Web 2.0

B7 softvérové aplikácie, ako napr. Microsoft PowerPoint využitel'né na tvorbu didaktických prezentácií edukačného obsahu s aplikovaním spätnoväzbových a multimediálnych prvkov podporujúcich výklad učitel'a vo vyučovacom procese a systematizáciu poznatkov žiakov

B8 softvérové aplikácie, ako napr. Microsoft Excel určené na spracovanie tabelovaných údajov využitel'ných $\mathrm{v}$ oblasti práce pedagogického zamestnanca regionálneho školstva

B9 softvérové aplikácie, ako napr. Microsoft Word určené na spracovanie a formátovanie vlastných textových dokumentov využitel'ných v oblasti práce pedagogického zamestnanca regionálneho školstva

Tab. č. 1: Zoznam posudzovaných tematických oblastí.

$\mathrm{K}$ rozsahu časovej dotácie predmetu, $\mathrm{v}$ rámci ktorého by sa príslušná učebná téma vyučovala, sa študenti vyjadrovali prostredníctvom vol'by jednej zo štyroch ponúkaných alternatívnych odpovedí na otázku: $V$ akom rozsahu by práca s uvedenými počitačovými aplikáciami mala byt' zaradená v študijnom programe učitel'stva? Alternatívne odpovede boli formulované nasledovne:

a) spolu s d’alšimi témami ako súčast' nejakého jednosemestrálneho vyučovacieho predmetu,

b) v rámci samostatného jednosemestrálneho vyučovacieho predmetu venovanému len tejto problematike,

c) v rámci samostatného dvojsemestrálneho vyučovacieho predmetu venovanému len tejto problematike,

d) výučbu tejto problematiky nie je potrebné zarad'ovat' do študijného programu učitel'stva.

Administrácia dotazníka bola realizovaná paralelne na Slovensku aj v Čechách v časovom období marec až máj 2019.

\section{Výsledky výskumného šetrenia}

Výsledky spracovania údajov získaných od respondentov sú sumarizované v Tab. č. 2 a v Tab. č. 3 . 


\begin{tabular}{|c|c|c|c|c|c|}
\hline \multirow{2}{*}{ Položka - tematická oblast’ } & \multirow{2}{*}{ Priemer } & \multirow{2}{*}{$\begin{array}{l}\text { Smerodajná } \\
\text { odchýlka }\end{array}$} & \multirow{2}{*}{$\begin{array}{l}\text { Smerodajná } \\
\text { chyba }\end{array}$} & \multicolumn{2}{|c|}{$\begin{array}{l}\text { Interval spol'ahlivosti } \\
\text { priemeru }\end{array}$} \\
\hline & & & & $-90 \%$ & $+95 \%$ \\
\hline $\begin{array}{r}\text { B1.1 - ActivInspire, SMART } \\
\text { Notebook, Flow!Works }\end{array}$ & 4,68 & 0,99 & 0,06 & 4,56 & 4,79 \\
\hline B2.1 - Prezi & 4,38 & 1,09 & 0,07 & 4,25 & 4,51 \\
\hline $\begin{array}{l}\text { B3.1 - FreeMind, Mindomo, } \\
\text { XMind }\end{array}$ & 4,42 & 1,11 & 0,07 & 4,29 & 4,55 \\
\hline $\begin{array}{l}\text { B4.1 - ActivExpression2, } \\
\text { ActivVote, } Q R F 700 / 900\end{array}$ & 4,15 & 1,21 & 0,07 & 4,00 & 4,29 \\
\hline B5.1 - Socrative 2.0 & 4,29 & 1,17 & 0,07 & 4,15 & 4,43 \\
\hline B6.1 - Google Dokumenty & 4,58 & 1,17 & 0,07 & 4,44 & 4,72 \\
\hline B7.1 - Microsoft PowerPoint & 5,25 & 1,08 & 0,06 & 5,12 & 5,38 \\
\hline B8.1 - Microsoft Excel & 5,06 & 1,09 & 0,07 & 4,93 & 5,19 \\
\hline B9.1 - Microsoft Word & 5,44 & 0,96 & 0,06 & 5,32 & 5,55 \\
\hline
\end{tabular}

Tab. č. 2: Miera významnosti/dôležitosti začlenenia jednotlivých druhov softvérových aplikácií B1 - B9 do kurikúl pregraduálnej prípravy učitel'ov.

$\mathrm{Z}$ údajov prezentovaných $\mathrm{v}$ Tab. č. 2 vidno, že hodnotenie významnosti jednotlivých druhov softvérových aplikácií (B1 - B9) v súvislosti s ich možným začlenením do študijných programov pregraduálnej prípravy učitel'ov zo strany respondentov bolo skôr pozitívne (vid' dosiahnuté priemery pri všetkých položkách v rozmedzí hodnôt od 4,15 do 5,44 pri maximálne možnej hodnote škály 6).

Významne najvyššia hodnota priemeru bola zaznamenaná pri položke B9 (B9.1), t. j. $\mathrm{v}$ prípade softvérovej aplikácie používanej na spracovanie a formátovanie vlastných textových dokumentov učitel'ov spojených $\mathrm{s}$ ich profesionálnou prácou a činnost'ami (Microsoft Word). Priemerné hodnotenie 5,44 (stredná hodnota medzi 5 - zaradit' až 6 rozhodne zaradit') dosiahnuté pri tejto položke ukazuje, že budúci učitelia považujú za potrebné zlepšit' si svoje zručnosti tak, aby v kontexte svojich budúcich profesijných aktivít dokázali uvedomele pracovat' so širším spektrom nástrojov textového editora. Vysoké priemerné hodnotenia na úrovni stupnice 5 boli zaznamenané aj v prípade d'alších dvoch položiek a to B7.1 a B8.1, čo znamená, že respondenti požadujú zaradit' do pregraduálnej prípravy učitel'ov aj výučbu práce so softvérovými aplikáciami Microsoft PowerPoint (B7) a Microsoft Excel (B8).

Hodnotenia potreby výučby aplikácií ActivInspire, SMART Notebook, Flow!Works (B1) a Google Dokumenty (B6) je v strede medzi asi je potrebné zaradit' (hodnota škály 4) a zaradit' (hodnota škály 5). Ostatné softvérové aplikácie sa dosiahnutým skóre v podstate všetky dostali do „pásma odporúčania“ na zaradenie do kurikúl študijných programov učitel'stva (dosiahnuté priemery skóre hodnotenia nad 4 - asi je potrebné zaradit').

Najnižšie priemerné skóre hodnotenia boli zaznamenané v prípade aplikácii Socrative 2.0 (B5.1 - 4,29) a ActivExpression2, resp. ActiVote, QRF700/900, SMART Response 2 (B4.1 - 4,15). Tieto aplikácie boli najčastejšie hodnotené ako tematické celky, 
problematiku ktorých nie je potrebné zarad'ovat' do študijných programov učitel'stva (vid' Tab. č. 3, relatívne početnosti odpovede $d$ pri B5.2-19,6\% a pri B $4.2-23,9 \%$ ).

Výsledky štatistickej analýzy hodnotenia miery významnosti zarad’ovania učebných tém z predmetnej oblasti do pregraduálnej prípravy učitel'ov z pohl'adu študentov učitel'stva uvádzané v Tab. č. 2 sú graficky vizualizované na grafe č. 1, ktorý zobrazuje bodový a intervalový odhad priemeru hodnotení jednotlivých položiek.

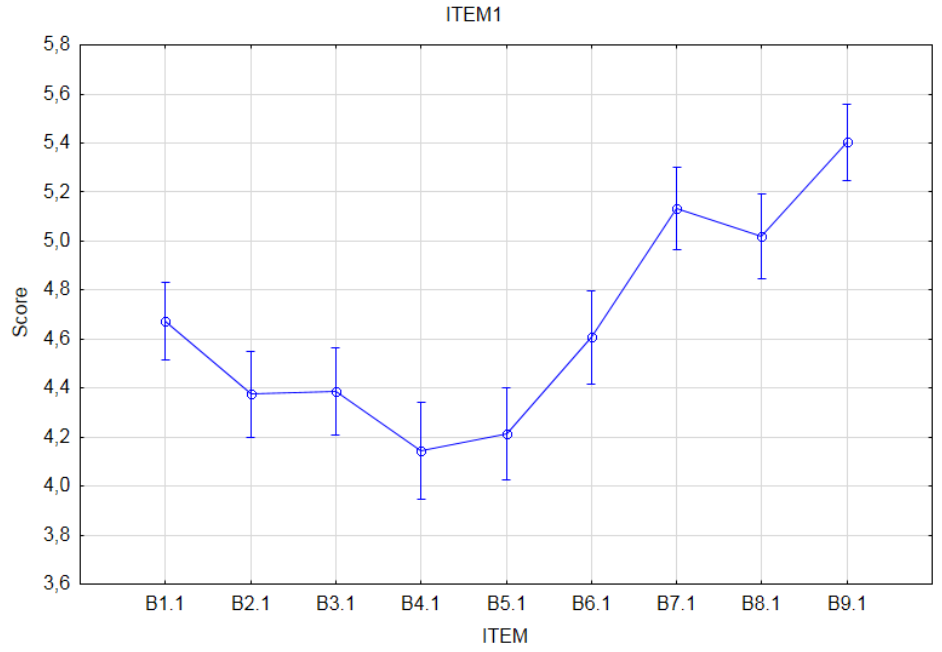

Graf č. 1: Vizualizácia rozdielov priemerných hodnôt skóre položiek B1.1 až B9.1.

Z grafickej interpretácie výsledkov (Graf č. 1) badat' mierny názorový odklon respondentov pri hodnotení položky B9 - tematickej oblasti zameranej na efektívne spracovanie a formátovanie vlastných textových dokumentov využitel'ných v práci učitel’a reprezentovanej počítačovou aplikáciou Microsoft Word a položky B7 - tematickej oblasti zameranej na tvorbu didaktických prezentácií edukačného obsahu podporujúcich výklad učitel'a vo vyučovaní a systematizáciu poznatkov žiakov prostredníctvom aplikácie Microsoft PowerPoint od hodnotenia zvyšných položiek.

Výsledky zistovania optimálneho rozsahu (časovej dotácie) predmetu, $\mathrm{v}$ rámci ktorého by sa mali vyučovat' jednotlivé tematické oblasti B1 - B9 sú prezentované v kontingenčnej tabul'ke početností (Tab. č. 3). Ide o celkové výsledky, absolútne a relatívne početnosti odpovedí všetkých respondentov bez ich diferenciácie do skupín v závislosti od segmentačných faktorov. K otázke rozsahu výučby práce s príslušnou softvérovou aplikáciou sa respondenti vyjadrovali prostredníctvom vol'by jednej zo štyroch ponúkaných alternatív (bližšie pozri čast' Metodika výskumného šetrenia), zvlášt' pre každú z príslušných softvérových aplikácií B1 - B9. 


\begin{tabular}{|c|c|c|c|c|}
\hline Položka / Odpoved' & $a$ & $b$ & $c$ & $d$ \\
\hline \multicolumn{5}{|l|}{ B1.2 } \\
\hline$\Sigma$ & $\begin{array}{l}122 \\
43,57 \%\end{array}$ & $\begin{array}{l}112 \\
40,00 \%\end{array}$ & $\begin{array}{l}34 \\
12,14 \%\end{array}$ & $\begin{array}{l}12 \\
4,29 \%\end{array}$ \\
\hline \multicolumn{5}{|l|}{ B2.2 } \\
\hline$\sum$ & $\begin{array}{l}146 \\
52,14 \%\end{array}$ & $\begin{array}{l}70 \\
25,00 \%\end{array}$ & $\begin{array}{l}21 \\
7,50 \%\end{array}$ & $\begin{array}{l}43 \\
15,36 \%\end{array}$ \\
\hline \multicolumn{5}{|l|}{ B3.2 } \\
\hline$\Sigma$ & $\begin{array}{l}142 \\
50,71 \%\end{array}$ & $\begin{array}{l}66 \\
23,57 \%\end{array}$ & $\begin{array}{l}34 \\
12,14 \%\end{array}$ & $\begin{array}{l}38 \\
13,57 \%\end{array}$ \\
\hline \multicolumn{5}{|l|}{ B4.2 } \\
\hline$\Sigma$ & $\begin{array}{l}122 \\
43,57 \%\end{array}$ & $\begin{array}{l}75 \\
26,79 \%\end{array}$ & $\begin{array}{l}16 \\
5,71 \%\end{array}$ & $\begin{array}{l}67 \\
23,93 \%\end{array}$ \\
\hline \multicolumn{5}{|l|}{ B5.2 } \\
\hline$\Sigma$ & $\begin{array}{l}130 \\
46,43 \%\end{array}$ & $\begin{array}{l}69 \\
24,64 \%\end{array}$ & $\begin{array}{l}26 \\
9,29 \%\end{array}$ & $\begin{array}{l}55 \\
19,64 \%\end{array}$ \\
\hline \multicolumn{5}{|l|}{ B6.2 } \\
\hline$\sum$ & $\begin{array}{l}157 \\
56,07 \%\end{array}$ & $\begin{array}{l}63 \\
22,50 \%\end{array}$ & $\begin{array}{l}19 \\
6,79 \%\end{array}$ & $\begin{array}{l}41 \\
14,64 \%\end{array}$ \\
\hline \multicolumn{5}{|l|}{ B7.2 } \\
\hline$\Sigma$ & $\begin{array}{l}146 \\
52,14 \%\end{array}$ & $\begin{array}{l}88 \\
31,43 \%\end{array}$ & $\begin{array}{l}25 \\
8,93 \%\end{array}$ & $\begin{array}{l}21 \\
7,50 \%\end{array}$ \\
\hline \multicolumn{5}{|l|}{ B8.2 } \\
\hline$\Sigma$ & $\begin{array}{l}157 \\
56,07 \%\end{array}$ & $\begin{array}{l}83 \\
29,64 \%\end{array}$ & $\begin{array}{l}23 \\
8,21 \%\end{array}$ & $\begin{array}{l}17 \\
6,07 \%\end{array}$ \\
\hline \multicolumn{5}{|l|}{ B9.2 } \\
\hline$\Sigma$ & $\begin{array}{l}155 \\
55,36 \%\end{array}$ & $\begin{array}{l}89 \\
31,79 \%\end{array}$ & $\begin{array}{l}23 \\
8,21 \%\end{array}$ & $\begin{array}{l}13 \\
4,64 \%\end{array}$ \\
\hline
\end{tabular}

Poznámka. a - spolu s d'alšími témami ako súčast' nejakého jednosemestrálneho vyučovacieho predmetu; $b-v$ rámci samostatného jednosemestrálneho vyučovacieho predmetu venovanému len tejto problematike; $c$-v rámci samostatného dvojsemestrálneho vyučovacieho predmetu venovanému len tejto problematike; $d$-výučbu tejto problematiky nie je potrebné zarad'ovat' do študijného programu učitel'stva

Tab. č. 3: Absolútne a relatívne početnosti odpovedí a - d zaznamenaných pri položkách B1.2 - B9.2.

Z Tab. č. 3 vidíme, že v prípade softvérových aplikácií B7 (Microsoft PowerPoint), B8 (Microsoft Excel) a B9 (Microsoft Word), ktoré respondenti dominantne požadujú zaradit' do študijných programov, boli zaznamenané zhodné požiadavky na ich časové dotácie. V podstate $55 \%$ respondentov sa domnieva, že výučba tematiky týkajúcej sa týchto aplikácií by mala byt' vyučovaná spolu s d’alšimi tematickými témami v rámci jednosemestrálneho predmetu (vol'ba odpovede $a$ ) a vodstate $30 \%$ respondentov navrhuje vyučovat' príslušné tematické okruhy $v$ rámci samostatných jednosemestrálnych predmetov (vol'ba odpovede $b$ ). Z percentuálneho hl'adiska približne štvrtina respondentov 
deklarovala pri týchto softvérových aplikáciách požiadavku zaradit' prácu s týmito aplikáciami samostatne, t. j. prácu s každou z týchto aplikácií ako dvojsemestrálny predmet venovaný výlučne len práci s týmito počitačovými produktmi (vol'ba odpovede $c$ ).

Čo sa týka vyučovania práce s d’alšími digitálnymi systémami a softvérovými aplikáciami, ako ukazujú prezentované výsledky (Tab. č. 3), pri digitálnych hlasovacích systémoch ActivExpression2, SMART Response 2, QRF700/900, TurningPoint a internetovej aplikácie Socrative 2.0 bola zaznamenaná najnižšia úroveň požiadavky na potrebu ich vyučovania.

\section{Diskusia}

Z prezentovaných výsledkov vyplýva, že s ohl'adom na svoje budúce profesijné pôsobenie študenti učitel'stva považujú za najdôležitejšie zaradit' do pregraduálnej prípravy učitel'ov problematiku efektívneho spracovania a formátovania vlastných textových dokumentov využitel'ných $\mathrm{v}$ oblasti práce pedagogického zamestnanca (Microsoft Word), tvorby didaktických prezentácií edukačného obsahu podporujúcich výklad učitel’a vo vyučovaní (Microsoft PowerPoint) a spracovávania tabelovaných údajov využitel'ných v oblasti práce pedagogického zamestnanca (Microsoft Excel).

Do určitej miery je to prekvapivý výsledok, nakol'ko so základmi práce s príslušnými softvérovými aplikáciami sú študenti väčšinou oboznamovaní už na nižších stupňoch vzdelávania. Je preto možné predpokladat', že na vysokú školu prichádzajú už s náležite rozvinutými schopnost’ami využívania týchto aplikácií. Ako však ukazujú výsledky realizovaného skríningu, rozsah a úroveň schopností pracovat's príslušnými softvérovými aplikáciami, ktoré študenti nadobúdajú na stredoškolskej úrovni vzdelávania, im neposkytujú pocit komfortnosti pri ich uplatňovaní v rámci svojej (budúcej) profesie. Na tomto mieste môže byt' vznesená námietka, že za týmto výsledkom sa môže skrývat' či už zámerná snaha alebo podvedomá tendencia respondentov dopytovania o „zámerné manipulovanie“ výsledkov skríningu tak, aby na ich základe vytvárané študijné programy umožňovali študentom „čo najl'ahšie“ štúdium. Opodstatnenost' tejto námietky však vyvracajú analýzy názorov študentov na rozsah, $\mathrm{v}$ akom by vyučovanie tejto problematiky malo byt' zaradené do študijných programov učitel'stva, a charakter predmetu, v rámci ktorého by príslušná tematická oblast' mala byt' vyučovaná. Výsledky skríningu názorov respondentov na položky B1 - B9 z aspektu charakteru predmetov (povinný, povinne volitel'ný, volitel'ný predmet), $\mathrm{v}$ rámci ktorých by dané tematické oblasti boli vyučované, v tomto príspevku vzhl'adom na limitovaný priestor prezentované nie sú (pre viac podrobností o týchto výsledkoch pozri Záhorec, Hašková a Munk, 2020).

Respondenti v podstate ku všetkým posudzovaným softvérovým aplikáciám (Tab. č. 1) najčastejšie prirad'ovali alternatívnu odpoved', podla ktorej by sa problematika práce s príslušnou aplikáciou mala vyučovat' spolu sd'alšimi témami ako súčast' jednosemestrálneho predmetu (alternatíva a). V prípade aplikácií Microsoft Word, Microsoft PowerPoint a Microsoft Excel boli však signifikantne vysoké aj početnosti výskytu odpovedí $b$ - samostatne v rámci jednosemestrálneho vyučovacieho predmetu venovanému len tejto problematike. $\mathrm{Z}$ globálneho hl'adiska hodnotení možno konštatovat', že pomer početností výskytu odpovedí $a$ a $b$ bol 2:1. Z percentuálneho hladiska približne štvrtina respondentov deklarovala pri týchto softvérových aplikáciách požiadavku zaradit' prácu s týmito aplikáciami samostatne, t. j. prácu s každou z týchto aplikácií ako 
dvojsemestrálny predmet venovaný výlučne len práci s týmito počítačovými produktmi (alternatíva odpovede $c$ ).

Napriek skutočnosti, že požiadavku, resp. požiadavky zaradenia práce s každou z týchto digitálnych aplikácií ako dvojsemestrálny predmet venovaný výlučne len práci s týmito softvérovými produktmi možno hodnotit ako pomerne výraznú, uvedomujeme si, že ju treba posudzovat' so značnou rezervou. Ich premietnutie do študijného programu by jednak viedlo k neúmernému navýšeniu predmetov zaradených do študijného programu (venujúcich sa výlučne formovaniu didakticko-technologických kompetencií učitel'ov) a súčasne aj $\mathrm{k}$ neúmerne zveličenému obsahu týchto predmetov. Navyše nepovažujeme za správne, aby pregraduálna príprava učitel’ov $\mathrm{v}$ oblasti rozvíjania ich didaktickotechnologických kompetencií bola zameraná na základné zručnosti práce s uvedenými softvérovými prostriedkami, nakol'ko základy týchto zručností majú študenti získavat' počas svojho stredoškolského štúdia. V prípade vykazovania nedostatočnej úrovne týchto schopností, eliminácia prípadných nedostatkov by mala byt' záležitost'ou napr. samovzdelávania študentov alebo absolvovania doplňujúcich kurzov, ale rozhodne by to nemalo byt' 'ažiskom náplne predmetov jadra príslušných študijných programov (ako to vyplýva $\mathrm{z}$ aktuálne zistených požiadaviek študentov). Obsahové zameranie predmetov jadra príslušných študijných programov je potrebné zamerat' na didaktické aspekty využívania softvérových aplikácií vo vyučovaní jednotlivých predmetov.

Čo sa týka zarad’ovania výučby problematiky využívania digitálnych hlasovacích systémov ActivExpression2/QRF700/900/SMART Response 2 a internetovej aplikácie Socrative 2.0 do študijných programov učitel'stva, v týchto dvoch prípadoch bola zaznamenaná najnižšia úroveň požiadavky na potrebu ich vyučovania. Pritom uvedené systémy patria medzi najaktuálnejšie hlasovacie nástroje tretej generácie. Zaznamenaný výsledok považujeme za dôsledok skutočnosti, že študenti nie sú dostatočne oboznámení s možnost’ami ich využívania, resp. celkovo s možnost’ami využívania elektronických hlasovacích systémov/zariadení v školskej praxi. Preto považujeme za dôležité, aby v učebných osnovách predmetov formujúcich didakticko-technologické kompetencie budúcich učitel'ov bola okrem nácviku práce s hlasovacími systémami akcentovaná aj problematika spôsobov ich využívania s ohl'adom na zvyšovanie efektivity výučby príslušného predmetu (využívanie hlasovacích systémov vo vyučovaní ako prostriedkov prispievajúcich $\mathrm{k}$ zvyšovaniu aktivity žiakov, zaujímavosti a atraktívnosti preberaného učiva, resp. vyučovacích situácií a pod.).

V súčasnosti sa vo väčšine študijných programov učitel'stva akcentuje práca s aplikáciami Microsoft Word, Excel alebo PowerPoint. Výučba príslušného predmetu, resp. predmetov sa pritom zameriava na rozvoj všeobecných užívatel'ských kompetencií (základné zručnosti súvisiace s možnost'ami, ktoré tieto produkty poskytujú), pričom $\mathrm{v}$ rámci kurikúl týchto predmetov absentuje zameranie na konkrétne možnosti aplikácie príslušných počítačových produktov do vyučovania jednotlivých predmetov. V značnej miere táto skutočnost' je dôsledkom heterogénnosti študentov $\mathrm{v}$ jednotlivých študijných skupinách (t. j. heterogenita špecializácí́ ich študijného zamerania na rôzne predmety). Z nášho pohl'adu považujeme za vhodné podl'a možností upravit' ponuku predmetov $\mathrm{v}$ zameraní ich obsahovej náplne $\mathrm{v}$ rámci možností tak, aby reflektovala aj predmetovú špecializáciu študijného zamerania jednotlivých skupín študentov. 
Aby mohli byt' naplnené očakávania študentov, bude potrebné zmenit' nielen obsahovú náplň predmetov rozvíjajúcich ich didakticko-technologické kompetencie, ale aj zarad’ovanie príslušných predmetov do študijných plánov. Súvisí to najmä $\mathrm{s}$ medzipredmetovou prepojenost'ou týchto predmetov s odborovými didaktikami. Odborové didaktiky sú $\mathrm{v}$ študijných programoch zaradené väčšinou vo vyšších ročníkoch (obvykle až v magisterskom stupni štúdia), kým predmety zamerané na rozvoj didaktickotechnologických kompetencií študentov (vzhl'adom na akcentovanie rozvoja všeobecnej užívatel'skej digitálnej gramotnosti študentov) sú zarad’ované do nižších ročníkov (obvykle v bakalárskom stupni štúdia). Pri súčasnom zarad’ovaní uvedených predmetov (v podstate v opačnej nadväznosti na seba) úplne prirodzene v rámci didakticko-technologickej prípravy študentov prevláda skôr „študentský“ ako „učitel'ský“ pohl'ad na možnosti využívania týchto prostriedkov (t. j. prevláda posudzovanie práce s týmito technológiami z pohl'adu študenta namiesto posudzovania práce s nimi z pohl'adu učitel'a). Eliminovat' tento problém by $\mathrm{z}$ nášho pohl'adu pomohlo posunutie predmetov didaktickotechnologickej prípravy do vyšších ročníkov štúdia.

\section{Záver a odporúčania}

Ako ukazujú výsledky rôznych výskumov (Uluyol a Sahin, 2016; Shopova, 2014; Ottestad, Kelentrić a Guðmundsdóttir, 2014), úspešnost' využívania digitálnych didaktických technológií počas školskej výučby závisí predovšetkým od osobnosti učitela a jeho nadobudnutých kompetencií v tejto oblasti modernej didaktiky. Preto je vel'mi dôležité kontinuálne udržiavat' náležitú úroveň didakticko-technologických kompetencií učitel'ov (Brečka, Valentová, 2019; Kostolanský, Šebo, Tomková, 2019; Kuna, Kozík, Kunová, Šebo, 2018).

Súčastou tejto úlohy je aj potreba neustále inovovat' pregraduálne vzdelávanie učitel'ov a to najmä v kontexte výkonu ich budúcej profesie. Výsledky realizovaného výskumného šetrenia naznačujú niektoré požiadavky, ktoré by sa mali prejavit' v inovácii kurikúl pregraduálnej prípravy učitel’ov zameraných na oblast' rozvoja profesijných didakticko-technologických kompetencií budúcich učitel'ov.

Hlavným zámerom projektu, $\mathrm{v}$ rámci ktorého bol realizovaný prezentovaný výskum, bolo vytvorenie platformy pre návrh optimálneho modelu pregraduálnej prípravy učitel’ov v oblasti didakticko-technologických kompetencií, sakcentom na formovanie ich profesijnej digitálnej gramotnosti. Touto platformou je návrh nasledujúcich odporúčaní:

Odporúčania týkajúce sa obsahovej náplne (kurikúl) prislušných predmetov:

- Do kurikúl týchto predmetov je potrebné zaradit' problematiku efektívneho spracovania a formátovania vlastných textových dokumentov a tabelovaných údajov využitel'ných $\mathrm{v}$ oblasti práce pedagogického zamestnanca a tvorby didaktických prezentácií edukačného obsahu podporujúcich výklad učitel’a vo vyučovaní.

- V súvislosti s nácvikom práce s digitálnymi hlasovacími systémami je potrebné dat' akcent na rôzne možnosti ich využívania s ohl'adom na zvyšovanie efektivity výučby príslušného predmetu.

Odporúčania týkajúce sa rozsahu výučby príslušnej problematiky:

- Kriticky zvážit' zarad’ovanie výučby práce s aplikáciami Microsoft Word, Microsoft PowerPoint a Microsoft Excel ako samostatných jednosemestrálnych predmetov 
venovaných len tejto problematike (požiadavka študentov) alebo ako doplňujúcich kurzov, resp. volitel'ných predmetov (vzhl'adom na deklarované profily absolventov stredných škôl, podla ktorých by študenti základné zručnosti práce s týmito aplikáciami mali mat' nadobudnuté už počas ich stredoškolského štúdia).

- Zvážit' možnosti výučby práce so všetkými posudzovanými softvérovými aplikáciami, pričom ako optimálna forma výučby bola najčastejšie volenou alternatívou alternatíva a - spolu s d’alšími témami ako súčast' nejakého jednosemestrálneho vyučovacieho predmetu.

Z nášho pohl'adu je potrebné upravit' ponuku predmetov tak, aby táto reflektovala vo väčšej miere predmetovú špecializáciu študentov učitel'stva (ich aprobačné predmety) a aby podl’a možnosti bola poskytovaná špecifická príprava $\mathrm{v}$ oblasti formovania didakticko-technologických kompetencií zvlášt' pre každú príslušnú skupinu študentov učitel'stva (t. j. diferencovane pre študentov učitel'stva spoločenskovedných predmetov, prírodovedných predmetov, cudzích jazykov, umelecko-výchovných a výchovných predmetov a profesijných a odborných predmetov). $\mathrm{V}$ súčasnosti totižto $\mathrm{v}$ rámci kurikúl týchto predmetov absentuje zameranie na konkrétne možnosti aplikácie príslušných softvérových produktov do vyučovania jednotlivých predmetov.

Odporúčania týkajúce sa zaradenia prislušných predmetov do študijných programov učitel'stva:

- Aby mohli byt' naplnené očakávania študentov od absolvovania príslušných výučbových predmetov, je potrebné inovovat' nielen obsahovú náplň týchto predmetov, ale je potrebné zmenit’ aj ich zaradenie do študijných plánov. Konkrétne sa odporúča presunút' predmety didakticko-technologickej prípravy do vyšších ročníkov štúdia (do magisterského stupňa).

Odporúčania týkajúce sa zaradenia nových predmetov do študijných programov učitel'stva:

- Popri vyššie uvedených odporúčaniach navrhujeme zaradit' do všeobecného základu študijných programov učitel'stva aj nové predmety, a to povinné, resp. povinne volitel'né - Tvorba interaktívnych foriem učebných materiálov, Interaktívne technológie hlasovania a hodnotenia vo výučbe a Aplikácie pedagogického softvéru vo vyučovaní.

\section{Pod'akovanie}

Táto práca bola podporená Kultúrnou a edukačnou grantovou agentúrou Ministerstva školstva, vedy, výskumu a športu Slovenskej republiky v rámci projektu 041UK-4/2017 KEGA a projektu 021UKF-4/2018.

\section{Literatúra}

Boboňová, I. a kol. (2017). Aplikácia metodiky hodnotenia kompetencii učitel'a: prípadové štúdie. Praha: Verbum.

Brečka, P., \& Valentová, M. (2019). Teaching strategies in pregraduate teacher training of technical subjects. EDULEARN19: 11th International Conference on Education and New Learning Technologies, 883-889. Palma de Mallorca: IATED Academy. 
Čeretková, S. a kol. (2019). Kompetencie učitela: hodnotenie, sebahodnotenie. Praha: Verbum.

Gadušová, Z. a kol. (2019). Nástroje hodnotenia kompetencii učitel'a. Praha: Verbum.

Kosová, B., Tomengová, A, a kol. (2015). Profesijná praktická príprava budúcich učitelov. Banská Bystrica: Belianum.

Kostolanský, L., Šebo, M., \& Tomková, V. (2019). The preparation of teachers in the field of multimedia education. EDULEARN19: 11th annual International Conference on Education and New Learning Technologie, 1477-1483. Palma de Mallorca : IATED Academy.

Kuna, P., Kozík, T., Kunová, S., \& Šebo, M. (2018). Software tools for creating and presenting virtual 3D models. Advances in Intelligent Systems and Computing : ICL 2017, Vol. 716, 17-26, Holtzbrinck: Springer.

Lomnický, I. a kol. (2017). Teoretické východiská a súvislosti hodnotenia kompetencií učitel'a. Praha: Verbum.

Magová, L. a kol. (2016). Hodnotenie kompetencií učitelov v európskom a slovenskom kontexte. Praha: Verbum.

Ottestad, G., Kelentrić, M., \& Guðmundsdóttir, G. (2014). Professional Digital Competence in Teacher Education. Nordic Journal of Digital Literacy, 9(4), 243-249.

Sandanusová, A. a kol. (2018). Reflexia aktuálnych poznatkov o kompetenciách učitel’a. Praha: Verbum.

Shopova, T. (2014). Digital literacy of students and its improvement at the university, Journal on Efficiency and Responsibility in Education and Science, 7(2), 26-32. https://doi.org/10.7160/eriesj.2014.070201

Stranovská, E. a kol. (2018). Výskum hodnotenia kompetencií učitel'a. Praha: Verbum.

Szíjjártóová, K. a kol. (2019). Pilotáž nástrojov hodnotenia kompetencií učitela. Praha: Verbum.

Uluyol, C., \& Sahin, S. (2016). Elementary school teachers' ICT use in the classroom and their motivators for using ICT, British Journal of Educational Technology, 47(1), 65-75. https://doi.org/10.1111/bjet.12220

Záhorec, J., Hašková, A., \& Munk, M. (2018). Particular results of a research aimed at curricula design of teacher training in the area of didactic technological competences. International Journal of Engineering Pedagogy, 8(4), 16-31, https://doi.org/10.3991/ijep.v8i4.8184

Záhorec, J., Hašková, A., \& Munk, M. (2019). Teachers' Professional Digital Literacy Skills and Their Upgrade. European Journal of Contemporary Education, 8(2), 378-393, DOI: 10.13187/ejced.2019.2.378.

Záhorec, J., Nagyová, A., \& Hašková, A. (2019). Teachers'attitudes to incorporation digital means in teaching process in relation to the subjects they teach. International Journal of Engineering Pedagogy, 9(4), 100-120.

Záhorec, J., Hašková, A., \& Munk, M. (2020). Digitálna gramotnost' učitel’ov v kontexte ich profesijnej pripravy. Bratislava : Univerzita Komenského v Bratislave, 1. vyd. 